\title{
PROGERIA (HUTCHINSON-GILFORD SYNDROME)
}

\section{REPORT OF A CASE AND REVIEW OF THE LITERATURE}

\author{
BY \\ JAMES THOMSON and JOHN O. FORFAR \\ From the Department of Medical Diseases of Children, University of St. Andrews and Royal \\ Infirmary, Dundee
}

(Received for Pubucation January 24, 1950)

. . the poor little boy didn't live to contrive, His health didn't thrive,

No longer alive,

He died an enfeebled old dotard at five.

W. S. GILBert (1869).

The first case of progeria to be described in medical literature was that of Hutchinson in 1886, under the title of ' Congenital Absence of Hair and Mammary Glands.' Hastings Gilford (1897) recognizing the condition as a clinical entity, described a case of his own (Figs. 1 and 2) and redescribed Hutchinson's original case. He introduced the

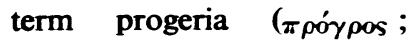
piematurely old). There is a tendency to use this term in connexion with other forms of early senility both in children and in adults but we agree with Crooke (1948) that it should be reserved for the specific syndrome first described by Hutchinson and Gilford.

Gilford considered it likely that a description of this syndrome would lead to the more frequent recognition of other cases and that it might be much more common than supposed. This opinion has not been borne out because we find that there has been no typical case of progeria reported in British literature since the original two cases, although Parsons (1949) and Ebbs (1949) have referred to a case and Keith (1913) has described a typical progerian skull. Cases have, however, been described in foreign literature and the outstanding feature of these descriptions is the striking similarity in appearance which all typical cases present. Variot and Pironneau (1910), unaware of Gilford's work, used the term nanisme senile in describing their case. A case described by Schippers (1916) was redescribed by Manschot (1940) 24 years later.

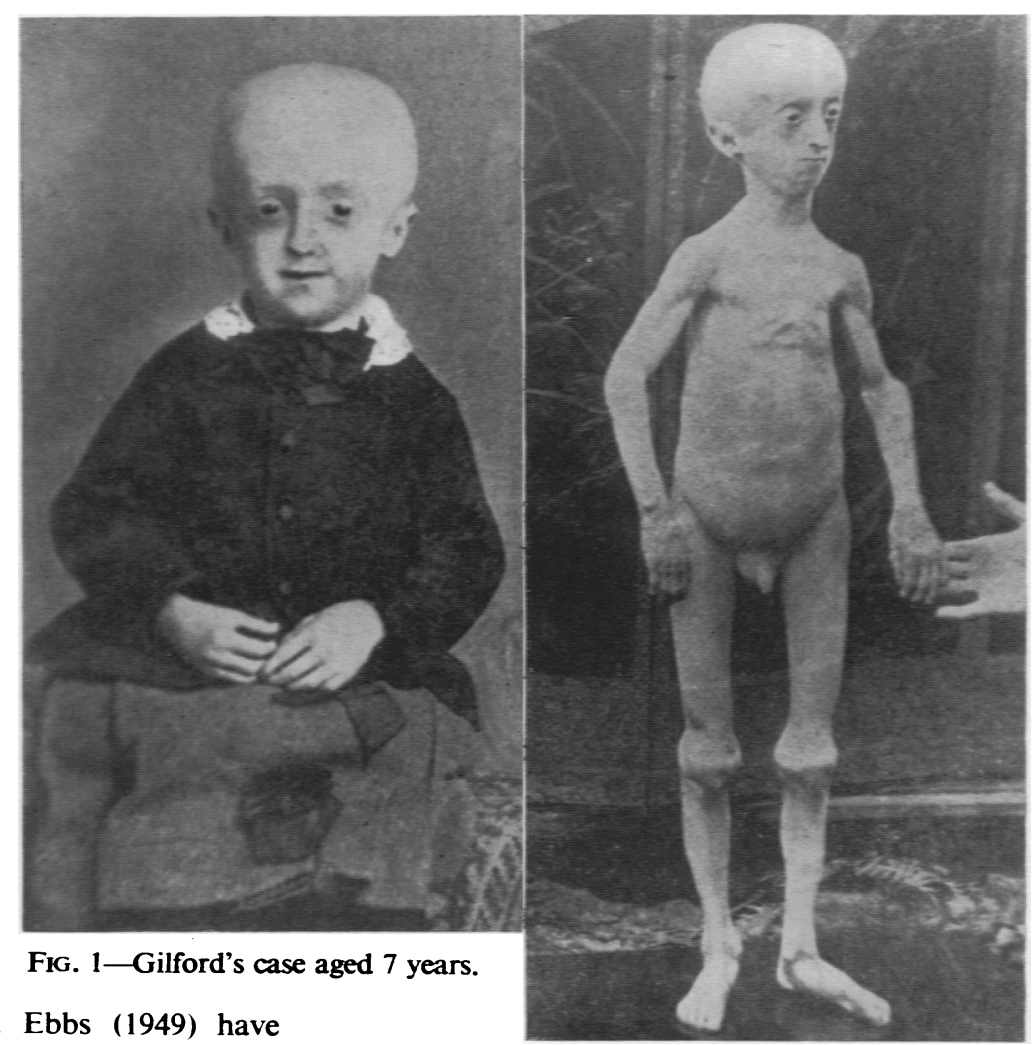

FiG. 2-Gilford's case aged 17 years. 
TABLE 1

Typical Cases of Progeria Recorded in the literature

\begin{tabular}{|c|c|c|c|c|c|c|c|c|c|c|c|}
\hline & & & & Sex & $\begin{array}{c}\text { Age } \\
\text { (years) }\end{array}$ & $\begin{array}{l}\text { Weight } \\
\text { (kg.) }\end{array}$ & $\begin{array}{l}\% \text { of } \\
\text { Expected } \\
\text { Weight }\end{array}$ & $\begin{array}{l}\text { Height } \\
\text { (cm.) }\end{array}$ & $\begin{array}{l}\% \text { of } \\
\text { Expected } \\
\text { Height }\end{array}$ & $\begin{array}{l}\text { Age at } \\
\text { Death }\end{array}$ & Necropsy \\
\hline 1 & $\begin{array}{l}\text { Hutchinson (1886) and } \\
\text { (1897) }\end{array}$ & $\begin{array}{l}\text { id Gilforc } \\
. .\end{array}$ & & M. & 15 & $17 \cdot 2$ & 33 & 109 & 67 & 17 & \\
\hline 2 & Gilford (1897) & $\ldots$ & -. & M. & 14 & $16 \cdot 3$ & 36 & 104 & 66 & 18 & $x$ \\
\hline 3 & Variot and Pironneau & (1910) & & F. & 15 & $11 \cdot 6$ & 23 & 102 & 64 & 15 & \\
\hline 4 & $\begin{array}{l}\text { Schippers (1916) } \\
\text { Manschot (1940) }\end{array}$ & $\begin{array}{l}\cdots \\
\cdots\end{array}$ & $\begin{array}{l}\cdots \\
\cdots\end{array}$ & M. & $\begin{array}{r}4 \\
26\end{array}$ & $\begin{array}{l}11 \cdot 3 \\
15 \cdot 6\end{array}$ & $\begin{array}{l}66 \\
26\end{array}$ & $\begin{array}{r}84 \\
115\end{array}$ & $\begin{array}{l}81 \\
67\end{array}$ & 26 & x \\
\hline 5 & $\begin{array}{l}\text { Oricco (1918) and Orr } \\
\text { Strada (1927) }\end{array}$ & $\begin{array}{l}\text { rrico and } \\
. \quad .\end{array}$ & $\begin{array}{l}\mathrm{d} \\
\cdots\end{array}$ & M. & 19 & $15 \cdot 4$ & 26 & 113 & 66 & 21 & $x$ \\
\hline 6 & Nasso (1925) $\ldots$ & . & .. & F. & $4 \frac{1}{2}$ & & & 83 & 81 & & \\
\hline 7 & Curtin and Kotzen ( & (1929) . & 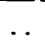 & F. & 7 & $11 \cdot 7$ & 54 & 96 & 80 & 9 & \\
\hline 8 & Strunz (1929) .. & . & 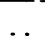 & F. & $6 \frac{1}{2}$ & $9 \cdot 4$ & 45 & 90 & 77 & & \\
\hline 9 & Thiers and Nahan (1 & (1933) & .. & M. & 19 & $23 \cdot 2$ & 39 & 131 & 77 & & \\
\hline 10 & Schiff (1934) & . & $\cdots$ & F. & $6 \frac{1}{2}$ & $\begin{array}{l}=4 \text { yrs. } \\
(16 \cdot 6)\end{array}$ & (79) & $\begin{array}{l}=4 \text { yrs. } \\
(100)\end{array}$ & (86) & & \\
\hline 11 & Exchaquet (1935b) & .. & . & F. & 14 & $12 \cdot 9$ & 28 & 113 & 73 & & \\
\hline 12 & Broc et al. (1935) & .. & . & M. & 11 & $14 \cdot 0$ & 42 & 116 & 82 & & \\
\hline 13 & Popek and Hadlik (19 & 938) & . & F. & 8 & $11 \cdot 2$ & 45 & 99 & 82 & & \\
\hline 14 & Mitchell and Goltmar & In (1940) & & F. & 10 & $12 \cdot 7$ & 42 & 105 & 78 & & \\
\hline 15 & Zeder (1940) $\ldots$ & . & .. & M. & 5 & $7 \cdot 6$ & 41 & 83 & 76 & & \\
\hline 16 & Schondel (1943) & . & . & F. & $5 \frac{1}{2}$ & $10 \cdot 9$ & 57 & 93 & 83 & & \\
\hline 17 & Talbot et al. (1945) & $\ldots$ & & M. & 6 & $10 \cdot 9$ & 51 & 95 & 81 & 7 & $x$ \\
\hline 18 & Schwartz and Cooke & e (1945) & & M. & 5 & $9 \cdot 8$ & 53 & 83 & 76 & & \\
\hline
\end{tabular}

Only 18 typical cases have so far been reported and these are enumerated in Table 1.

The cases described by Rand (1914), Lereboullet (1917), Farran-Ridge (1921), Paterson (1922), Talbot (1923), Harris (1927), Apert and Robin (1927), Apert (1933), Stoia and Andreoiu (1928), Halle and Odinet (1932), Pouzin-Malègue and Barraud $(1932,1934)$, Martinez (1935), Heuyer, Denoyelle, and Bernard (1936), Stern and Lieberman (1937), Schachter-Nancy (1938), Sundblad (1938), Korsgaard (1940), MūllerHess (1940), Gottron (1940), Schondel (1942second case), Nery (1944), Moehlig (1946), van Bolhuis (1948), and Wiedemann (1948) are not in our opinion typical cases of progeria.

Most of these cases show, however, some of the manifestations of progeria but all of them lack some of the characteristic features of typical cases. The clinical picture in progeria is so clear cut that we do not feel justified in including such variants in it. It may be that whereas progeria represents a total pathological lesion some of these atypical cases represent a partial lesion of the same nature or that in other cases the clinical picture has been modified by the occurrence at a later age period of the pathological processes responsible for progeria. Gilford (1911a) has described a possible case modified in this way by later age of onset. Gorter (1942) in describing a boy showing some of the signs of progeria, but lacking others, has suggested that the term progeroid be applied to cases of this type, that of progeria being reserved for classical cases. There seem to be good grounds for making 
a distinction and grouping of this sort. Waldorp and del Castillo (1928) had previously suggested the term gero-dystrophic infantilism for atypical cases.

Gilford (1902, 1904a, 1904b, 1911a, 1911b, 1913) has discussed the subject of progeria at length and it has been reviewed by Apert and Robin (1927), Curtin and Kotzen (1929), Atkinson (1937), Schachter-Nancy (1938), Mitchell and Goltman (1940), Schondel (1943), Gorter (1942), and Wiedemann (1948).

\section{Report of a Case}

History. S.R. came under our observation on September 21, 1946, when he was 22 months old on account of failure to gain weight (Figs. 3 and 4). He has been examined at intervals over a period of two and a half years, and the present description (June, 1949) refers to his condition at $4 \frac{1}{2}$ years of age.

His mother did not suffer from any illness throughout her pregnancy. Normal delivery took place at term and the birth weight was $5 \mathrm{lb}$. 4 oz. (2,382 g.). No abnormality was noted at that time. A normal amount of scalp hair was present and the skin appeared to be of normal texture.

$\mathrm{He}$ is the first child of the present marriage. His

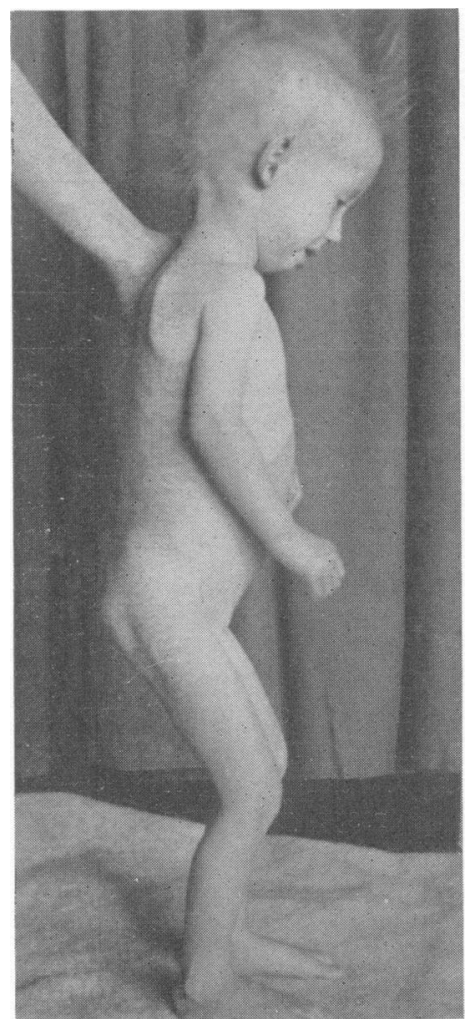

FIG. 3-S.R. aged $1 \frac{3}{4}$ years showing typical stance. mother, by a previous marriage, has another male child aged 11 years who is normal. There have been no stillbirths or miscarriages. Father, mother, and halfbrother are well, and have not suffered from any relevant illnesses. The mother is of average stature, but the father's stature is below average; he has a small head and poorly developed chin but in no other detail does he resemble his son. No history of a b normal physical development in other relatives has been obtained.

S.R. was breast f e d for t w o months and fed $t h$ e reafter on National Dried Milk and cow's milk. His mother

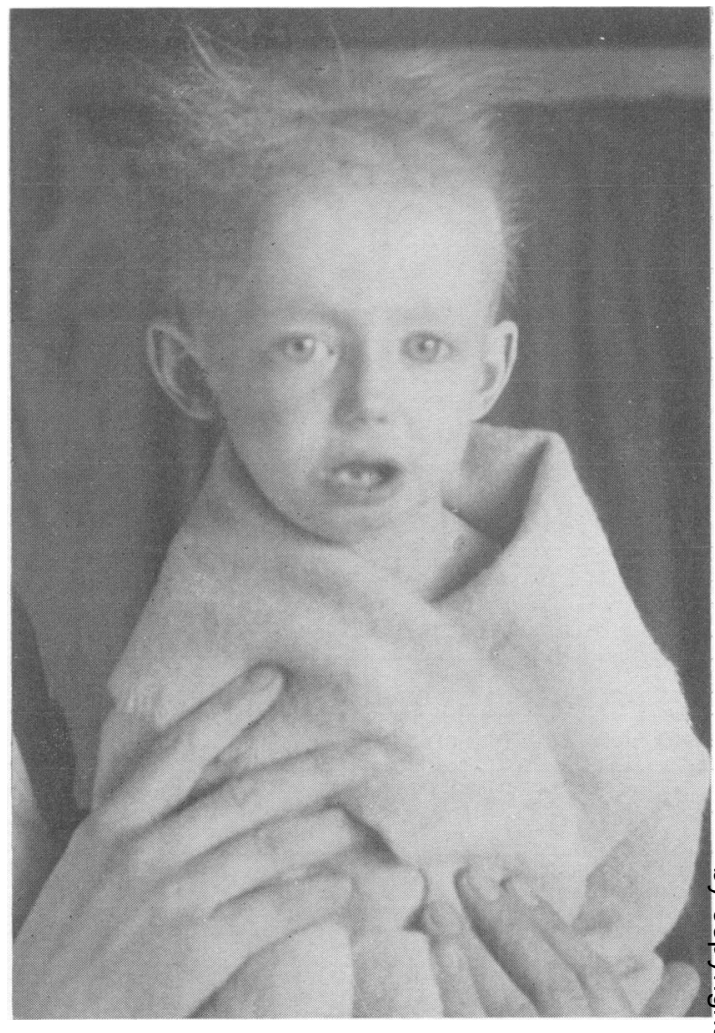

FIG. 4-S.R. aged $1 \frac{3}{4}$ years. Scanty hair and crowded lower teeth.

described him as 'a difficult feeder.' One teaspoonful $\stackrel{\circ}{\varnothing}$ of cod liver oil was given daily when three months old $\stackrel{2}{\rightarrow}$ but this was continued for only a few months. He음 received no additional vitamin $\mathrm{C}$. He was a contented baby and apart from difficulty in feeding and poor appetite he remained well until the age of 18 months, his growth approximating to that of a normal child. $\mathrm{He}$ sat up at 7 months, began to talk at the same age and walked at 9 months. His first tooth did not appear until he was over one year old.

When he was about 20 months old his parents began to realize that he was only gaining weight very slowly and was looking thinner. His hair was becoming sparse. His appetite remained poor. He has become increasingly $\mathrm{S}$ bald and prominent scalp veins have been noticed. A change in the facies to a sharp pinched appearance has occurred and he has gradually become thinner. Duringn the last two and a half years his weight has increased by 0 just over $4 \mathrm{lb}$. as against an expected gain of almost $10 \mathrm{lb} . \mathrm{N}$

His mother considers him to be well advanced $N_{\omega}$ intellectually for his age. $\mathrm{He}$ is fond of playing with companions, likes to be the centre of attraction, and is easily offended. He prefers playing with toys to looking at books, likes to sing and does so in a high pitched voice. He sleeps well but when asleep his eyes remain half open. 
TABLE 2

Measurements of Present Case Compared with those of an Average Boy i eqe $4 /$ hups

S.R.

Normal

\begin{tabular}{|c|c|c|c|c|c|c|c|c|}
\hline Weight & . & . & . & . & .. & .. & 19 lb. 14 oz. $(9 \cdot 0 \mathrm{~kg})$. & 37 lb. 5 oz. $(16.9$ kg. $)$ \\
\hline Height & . & . & .. & . & .. & . & 35 in. $(88.9 \mathrm{~cm})$. & $41 \cdot 5$ in. $(105 \cdot 4 \mathrm{~cm})$. \\
\hline \multicolumn{2}{|l|}{ Head circumference } & . & .. & . & . & . & $18 \frac{3}{4}$ in. $(47 \cdot 6 \mathrm{~cm})$. & 20 in. $(50.8 \mathrm{~cm})$. \\
\hline \multicolumn{2}{|l|}{ Length of clavicle } & . & .. & . & .. & . & $2 \frac{3}{8}$ in. $(6.03 \mathrm{~cm})$. & $3 \frac{1}{2}$ in. $(8.9 \mathrm{~cm})$. \\
\hline \multicolumn{2}{|l|}{ Head-umbilicus } & . & .. & . & .. & . & $16 \frac{1}{2}$ in. $(41 \cdot 9 \mathrm{~cm})$. & 20 in. $(50 \cdot 8 \mathrm{~cm})$. \\
\hline \multicolumn{2}{|l|}{ Umbilicus-feet .. } & . & .. & . & .. & . & $18 \frac{1}{2}$ in. $(47 \cdot 0 \mathrm{~cm})$. & $21 \frac{1}{2}$ in. $(54.6 \mathrm{~cm})$. \\
\hline \multicolumn{2}{|l|}{ Length of lower limbs } & .. & .. & . & .. & . & $19 \frac{1}{1}$ in. $(48.9 \mathrm{~cm})$. & 20 in. $(50 \cdot 8 \mathrm{~cm})$. \\
\hline \multicolumn{2}{|c|}{ Length of upper limbs .. } & .. & .. & . & . & .. & 16 in. $(40 \cdot 6 \mathrm{~cm})$. & 18 in. $(45 \cdot 7 \mathrm{~cm})$. \\
\hline \multicolumn{3}{|c|}{ Chest circumference (at nipple) } & .. & . & & .. & 17 in. $(43 \cdot 2 \mathrm{~cm})$. & 22 in. $(55.9 \mathrm{~cm})$. \\
\hline \multicolumn{4}{|c|}{ Abdominal circumference (at umbilicus) } & $\cdots$ & $\cdots$ & $\cdots$ & $18 \frac{1}{2}$ in. $(47 \cdot 0 \mathrm{~cm})$. & 19 in. $(48 \cdot 3 \mathrm{~cm})$. \\
\hline
\end{tabular}

His limit of walking is half a mile but otherwise he has not been noted to tire unduly easily and dyspnoea has not been marked. He does not sweat much. There is a tendency to constipation. When he becomes excited or on exertion a soft 'rushing' sound is heard in his head by those sitting close to him.

The general appearance of the patient when we examined him in June, 1949, was striking. In his smallness of - stature, his restless activity, his impish behaviour and ready recourse to tears, his high-pitched, piping voice and his interest in playthings, he was a small boy; in his thinness and absence of subcutaneous fat, his bald head and pinched facies, his dry, atrophic, inelastic skin, his wrinkled hands, his bent posture and slightly fiexed joints, he was an old man.

His demeanour on examination was shy and resentful to begin with but determined, even assertive, when he became accustomed to the examiner. $\mathrm{He}$ was easily upset and had a quick temper. If thwarted he showed the irascibility of old age.

His measurements contrasted with those of an average boy of the same age are set out in Table 2 .

The head suggested a slight degree of hydrocephalus but this was due to the smallness of the face and not to true hydrocephalus. The circumference of the head was actually less than that expected. The fontanelle was closed (closed on first examination when aged 22 manths). Apart from a few almost white downy hairs the head was completely bald giving a 'plucked bird' appearance. The skin over the cranium was thin and tightly drawn and could not be raised easily into folds. Scalp veins were prominent and distended (Fig. 5). The face was small, the skin glazed and atrophic, and the nasal cartilages conspicuous. There was a complete absence of eyebrows and eyelashes and the eyes were prominent. The ears stood out but the lobules were poorly developed. The tympanic membranes were normal. The lips were thin and the mouth small. The lower jaw was small and receding (Fig. 6). There was no limitation of the range of movement of the temporo-mandibular joint. The tongue was smooth. The tonsils were not enlarged and the cervical lymph glands were impalpable. The palate was not unduly arched. Sixteen teeth were present, the posterior molars being absent. Due to the small size of the lower jaw the teeth there were crowded together, the central incisors being rotated and displaced backwards. The submaxillary glands and the thyroid gland were palpable. The temperature was normal.

The thorax was pyriform in shape, the narrowed inlet being associated with very short clavicles. Prominence of the ribs and absence of subcutaneous fat were marked. The nipples were present but small. The chest circumference was less than normal and the chest expansion was $\frac{1}{2}$ in. The respiration rate was 24 per minute. The percussion note over the lungs was resonant and the breath sounds vesicular. There were no adventitious sounds. There was no visible praecordial pulsation, the apex beat being palpable in the fifth left interspace just within the nipple line. On percussion the upper border of cardiac dullness was at the level of the third rib, the right border being at the mid-sternal line. The pulse was regular and the pulse rate was 116 per minute. Sinus arrhythmia was not present. Auscultation revealed a widespread systolic murmur heard over the whole praecordium but most intense over the third left costal cartilage. This murmur was conducted loudly up both carotids to the mastoid processes and then converged to an area of maximum intensity over the occiput where a bruit almost musical in quality and loud enough to be heard on occasions without a stethoscope was present. Pressure over the carotids did not abolish the bruit. The blood pressure was 10664 . He was considered to be suffering from a congenital cardiac lesion although the precise type was not identified. No hardening of the radial or temporal arteries was detected.

The abdomen was full and this in association with the 


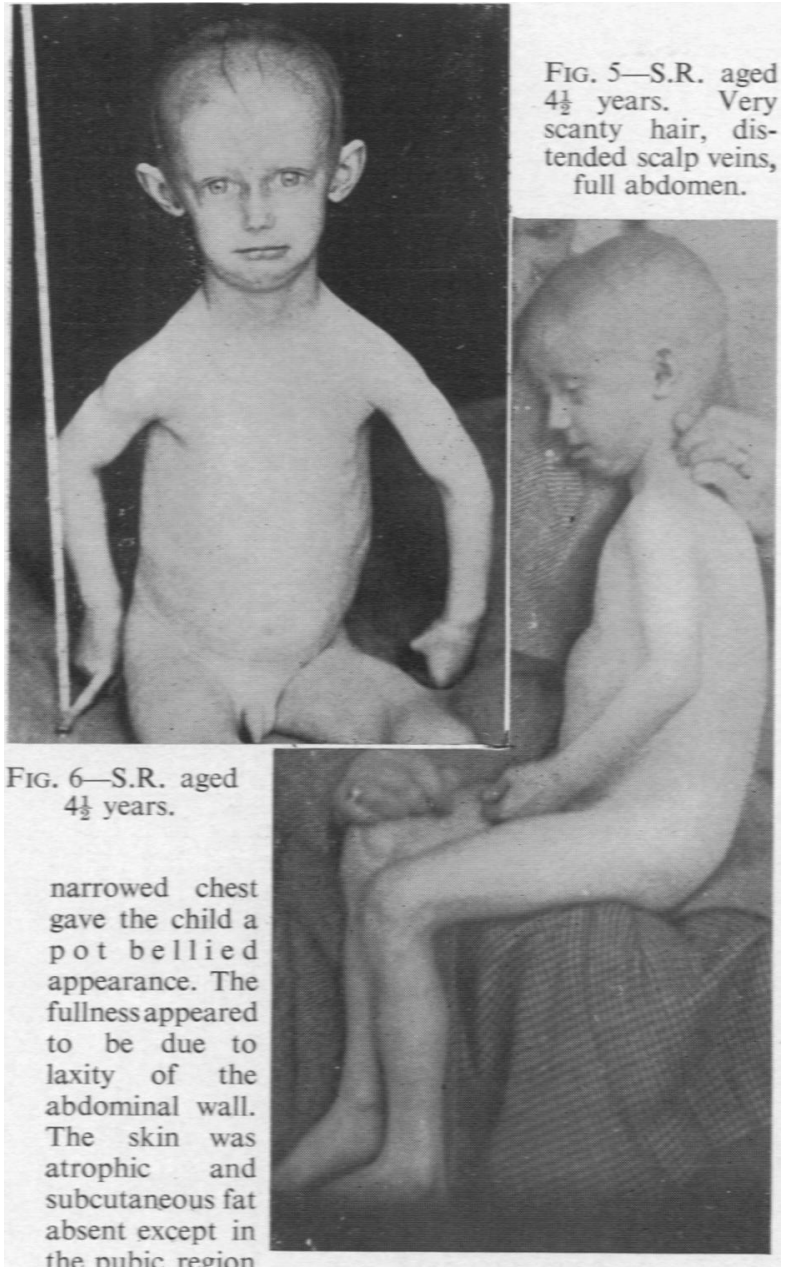

region

where an isolated pad was present. The umbilical depression was obliterated. The liver was not enlarged and the spleen and kidneys were not palpable. There was no abdominal tenderness. The genitalia were of normal development for his age, the scrotum showing the usual rugosity.

Examination of the central nervous system revealed no abnormality of the deep or superficial reflexes. The pupils were equal and reacted to light and accommodation. There was no squint, nystagmus, or abnormality of the optic fundi. Motor power was fair and no abnormalities of sensation were detected.

The limbs were very thin, especially distally, and this thinness accentuated the joint enlargement, particularly of the knees and the knuckles. The hands were small and senile in appearance with wrinkled dorsal skin. There was slight enlargement at the interphalangeal joints and inability to extend these joints fully. The interossei muscles were atrophied. The nails were shortened and their width exceeded their length. The knees and hip joints could not be extended through their full range. There was the typical 'horse riding' stance, the knees and hips a little flexed, the trunk and head held forward with the eyes raised to compensate for this, the arms adducted and slightly flexed at the elbows, the wrists in the mid position between pronation and supination and the fingers flexed (Fig. 7). The gait was straddling but he could run fairly well in rather a flat footed manner.

Special Investigations. - Urine Acid. Specific gravity, 1,010. Albumin, a trace. No sugar. Urobilinogen, a trace. Urinary output in 24 hours, $362 \mathrm{ml}$. Urea output per 24 hours, $6.9 \mathrm{~g}$. Urinary creatine output per 24 hours, $121 \cdot 8 \mathrm{mg}$. Creatinine output per 24 hours, $165 \cdot 0$ mg. Creatine/ creatinine ratio, $74^{\circ}$ ( normal $40 \%$ ). Creatinine coefficient, $18 \cdot 5$ (normal 15-27-5). Secretion of 17ketosteroids per 24 hours (as androsterone), $2 \cdot 85 \mathrm{mg}$. (normal 0.8-2. $6 \mathrm{mg}$.).

BLood. Haemoglobin (Sahli), $76^{\circ}$. Red blood cells, 4,000,000 per c.mm. White blood cells 6,400 per c.mm. Erythrocyte sedimentation rate, $22 \mathrm{~mm}$. per hour (micro - method, normal<10). Blood urea 48 mg. ${ }^{o}$ o. Blood sugar (f asting), $90 \mathrm{mg} .{ }^{\circ}$. Blood cholesterol, 275

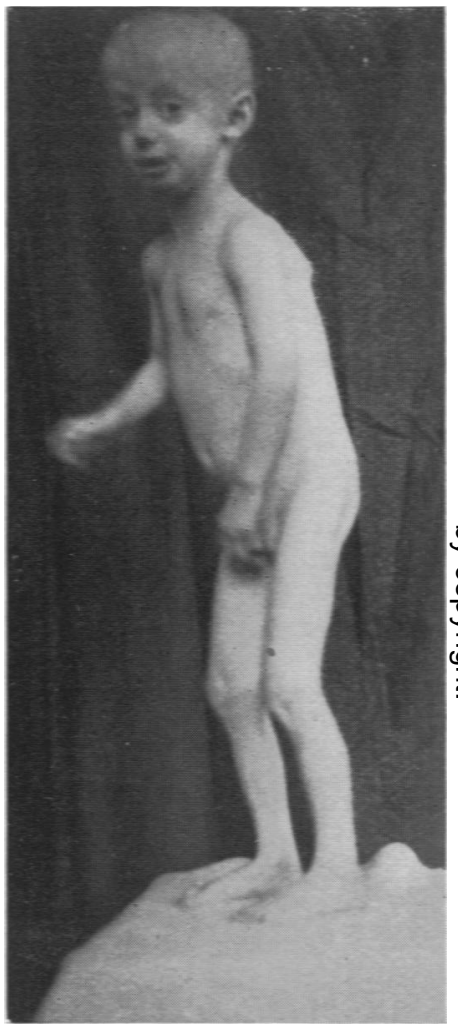

FIG. 7-S.R. aged $4 \frac{1}{2}$ years. mg. ${ }^{\circ}$. Total plasma protein, $7 \cdot 25 \mathrm{~g}$. ${ }_{0}$. Plasma albumin, 5.00 g. ${ }^{\circ}$. Plasma globulin plus fibrinogen, $2 \cdot 25 \mathrm{~g}$. ${ }^{\circ}{ }_{0}$. Serum calcium, $11 \cdot 1 \mathrm{mg}$. ${ }^{\circ}{ }_{0}$ Plasma acid phosphatase $3 \mathrm{King}$ Armstrong units ${ }^{\circ}{ }_{0}$. Plasma alkaline phosphatase 7 King Armstrong units ${ }_{0}{ }_{0}$. Wassermann reaction, negative. (Maternal and paternal Wassermann reactions, negative.)

Cerebrospinal Flutid. Fluid clear and under normal pressure. Protein, $10 \mathrm{mg}$. \%. No pleocytosis. Lange reaction, 0000000000. Sugar present. Wassermann reaction, negative.

Electrocardiographic. Tracing showed regular rhythm of sinus origin. No sinus arrhythmia present. Heart rate, 108 per minute. PR interval, $0 \cdot 10$ secs. QRS complex $M$ shaped in lead III. 
Radiological. The cranial wall was thin. There was no premature synostosis. The pituitary fossa was enlarged beyond normal limits (Fig. 8). There was no anodontia, the unerupted molars being seen. The

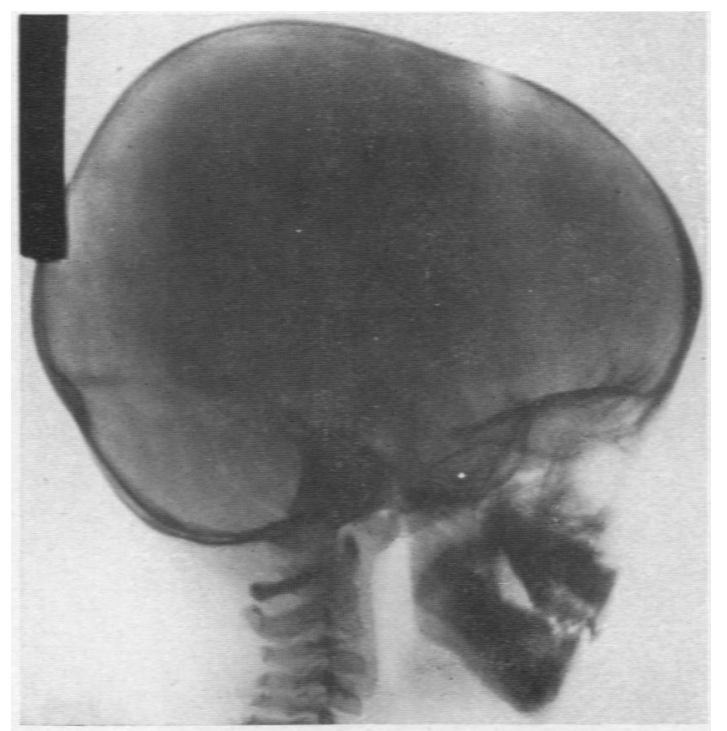

FIG. 8.

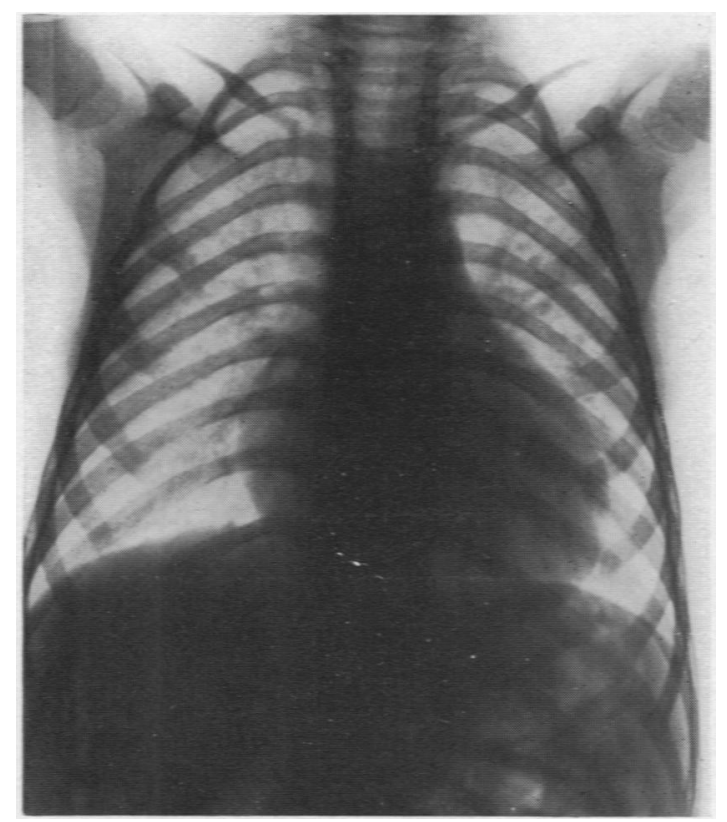

FiG. 9.

Figs. 8, 9 and 10. Radiological appearance of skull, chest and pelvis. degree of calcification of the permanent dentition corresponded with his age.

The lung fields were clear. The heart was not enlarged and showed normal configuration. The clavicles were short and thin and the ribs narrow (Fig. 9).

Spina bifida of the first sacral segment was seen on stereoscopic examination, and on lateral view the vertebrae were of the ovoid infantile type.

Marked bilateral coxa valga was present (Fig. 10).

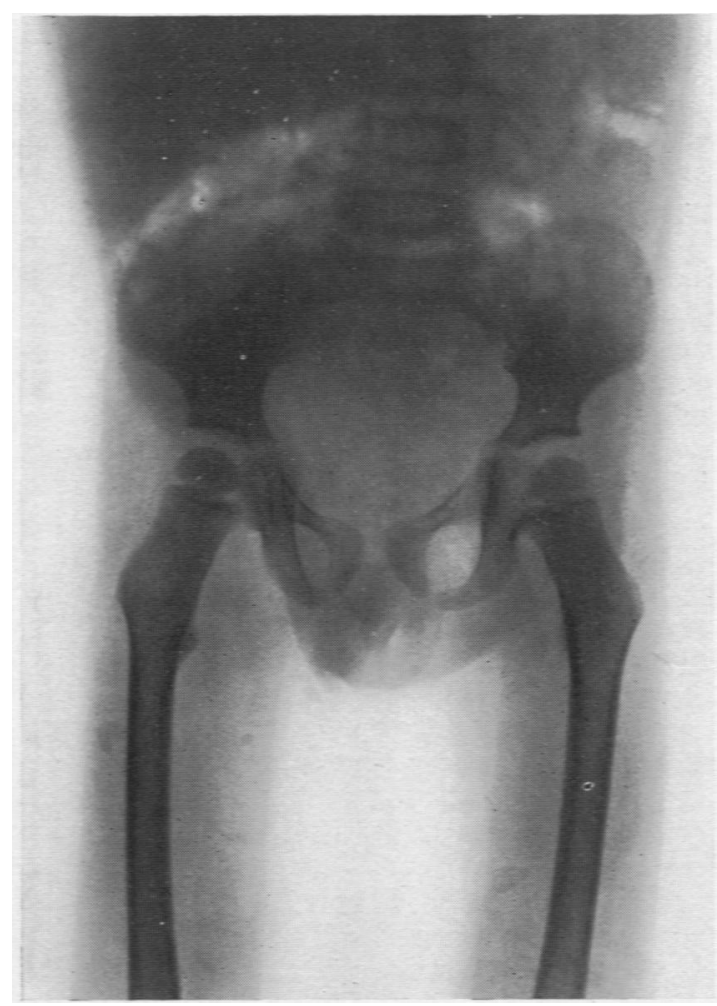

Fig. 10.

At the age of $3 \frac{1}{2}$ years the ischial and pubic rami had almost fused as compared with a normal age of fusion of 4 to 5 years.

The shafts of the long bones were slender, the ends being of normal width. At the age of 22 months the state of ossification of the ankle and foot was slightly in advance of that expected. At the age of $4 \frac{1}{2}$ years the carpus showed an ossification age of 3 to $3 \frac{1}{2}$ years (Fig. 11).

An intravenous pyelogram showed normal excretion of dye and no abnormality of the kidney pelves, ureters, or bladder.

\section{Discussion}

Clinical Features. The case here described exemplifies most of the classical clinical features of 
progeria as seen at this age. Cases have been distributed widely throughout the world and a case in a negro has been described (Schwartz and Cooke, 1945). In a few cases there has been a history of maternal illness during pregnancy (Gilford, 1897; Curtin and Kotzen, 1929; Popek and Hadlik, 1938), no specific illness appearing to be significant.

The average birth weight in ten cases where this was stated was $5 \mathrm{lb} .13 \mathrm{oz}$. (2.65 kg.) and apart from prematurity in some instances (Variot and Pironneau, 1910; Curtin and Kotzen; Broc, Nicolle, and de Beaujeau, 1935) no abnormality was noted at birth, failure to gain in weight and loss of hair in the second year of life being the usual reasons causing parents to seek medical advice. There is no apparent hereditary or familial factor nor relationship with the parity of the mother. The sex incidence is equal. The initial failure to gain in weight and stature develops gradually into one of dwarfism. Fig. 12 compares graphically the growth in weight curves in progeria and in normal individuals. Fig. 13 compares the corresponding growth in height curves. It will be noted that up to the second year there is only slight retardation of growth but that thereafter it is very slow, $36 \mathrm{lb}$. $(16 \cdot 5 \mathrm{~kg}$.) being estimated as the average weight reached at the age of 18 years and $46 \mathrm{in}$. $(117 \mathrm{~cm}$.) the average height at the same age. The average age at death in seven cases was 161 years, the oldest recorded case surviving until the age of 26 years (Manschot, 1940).

Walking and speaking have occurred early in some cases but in a few have been delayed. The primary dentition is delayed. Appetite may be very good or poor. An undue sensitivity to heat and cold has been noted in certain cases (Gilford, 1897; Mitchell and Goltman, 1940). Sleeping with the eyes half open has also been reported by Zeder (1940).

All cases show a striking resemblance in physical features and in body configuration. The facial features are quite unlike those of other members of their families, but compared with other cases of progeria at similar ages are remarkably alike, so much so that Gilford writing of his two cases tells how the father of one of them, when shown a photograph of the other, thought at first that he was looking at a portrait of his own son. Due to the smallness of the face all have a hydrocephalic look and the relative reduction in the size of the orbital cavities is probably responsible for the prominence of the eyes. A case in which there was microphthalmia has been reported by Schondel (1943). Prominent dilated scalp veins are invariably present. Frequently the palate has been high and arched and the fontanelle late in closing. Micrognathia involving the lower jaw always occurs, with crowding and irregularity of the teeth, especially the incisors.

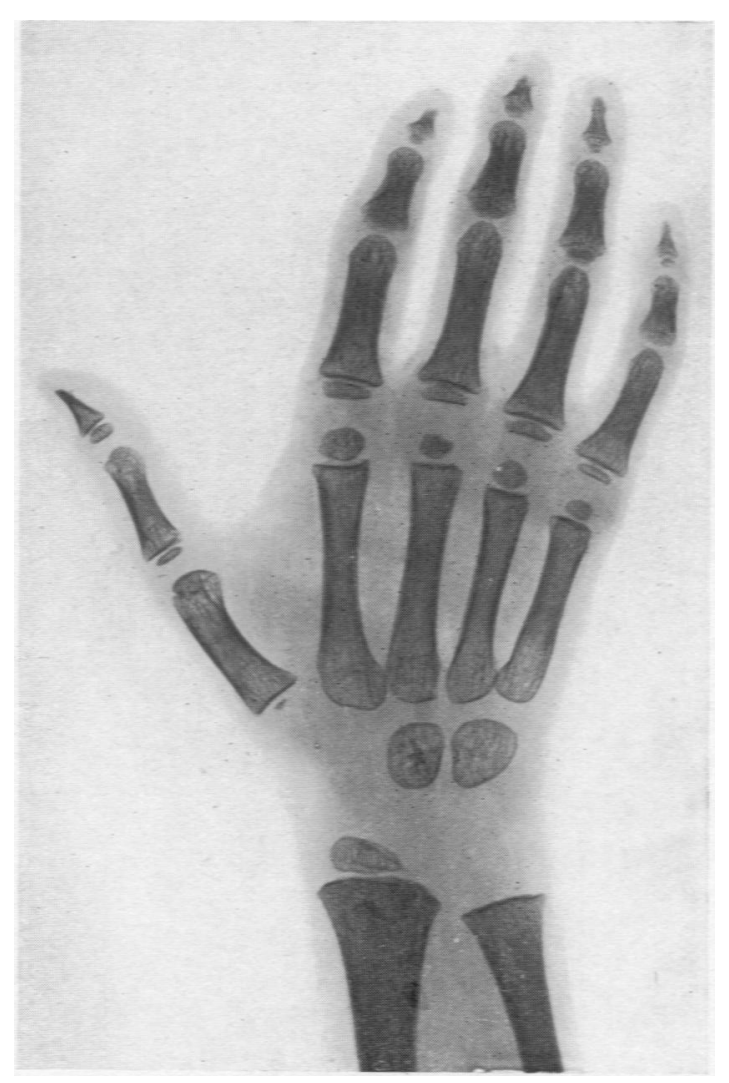

FIG. 11.-Radiograph showing ossification age of the carpus of 3 to $3 \frac{1}{2}$ years.

Some of the teeth may be absent. Baldness and absence of the eyebrows and eyelashes, the atrophic, inelastic state of the skin, and the absence of subcutaneous fat except in the pubic region are marked in all cases. In some, small pigmented or unpigmented spots on the skin have been noted, and in some, the nails have been furrowed and membranous. In three cases (Strunz, 1926 ; Exchaquet, 1935a and b, and Zeder, 1940) the condition has been associated with sclerodermia.

The clavicles are characteristically short and the thorax pyriform in shape, contrasting with the prominent abdomen below. The ribs are usually prominent. The umbilical depression is obliterated. The heart is not enlarged but cardiac murmurs are frequently present. Cranial bruits have been noted previously by Talbot, Butler, Pratt, MacLachlan, and Tannheimer (1945). The possible vascular abnormalities associated with such bruits have been discussed by Hamburger (1931). The blood pressure is normal. Schwartz and Cooke (1945) have recorded 


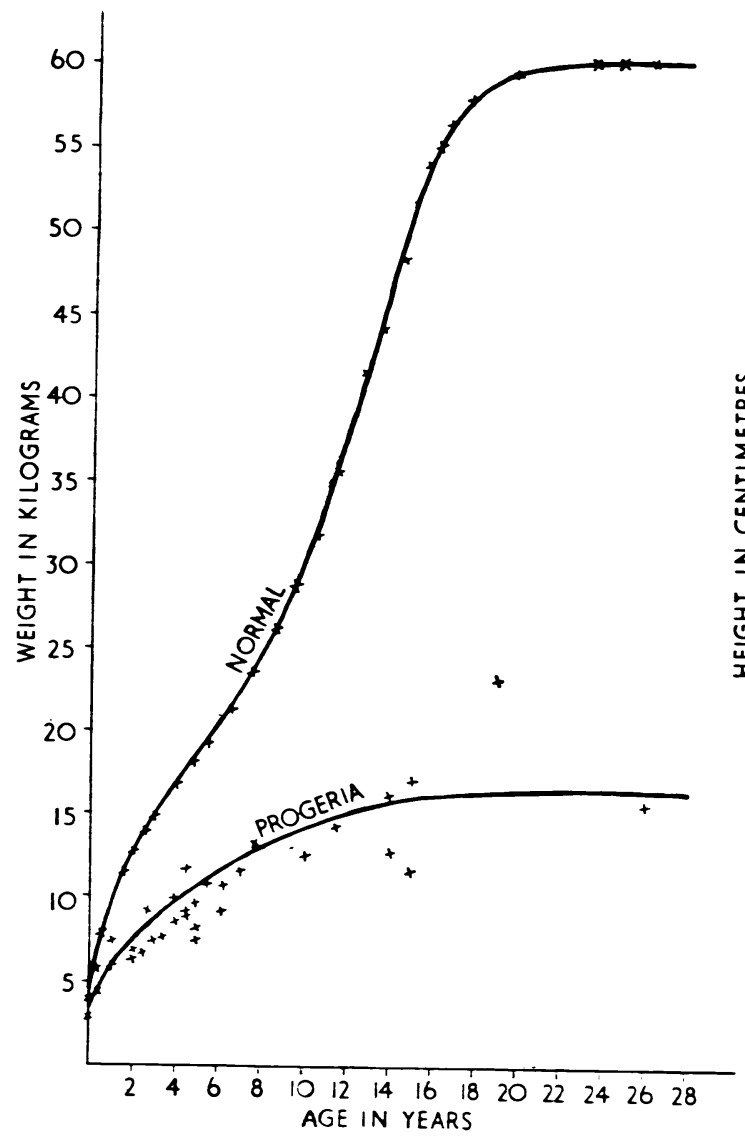

Fig. 12.-Growth in weight curves in the normal (after Mitchell-Nelson) and in Progeria.

arteriosclerotic changes as early as the fifth year and these are a well marked feature of all older cases. The genitalia are normal until the age of puberty but in the few reported cases beyond the age of adolescence there has been little evidence of sexual maturity. Spermatogenesis has been reported in one case (Gilford, 1897), but in other cases (Orrico and Strada, 1927; Talbot et al., 1945) no evidence of this was found on post-mortem examination.

No characteristic central nervous system abnormalities have been noted.

The muscles are poorly developed and the limbs are thin. There is some enlargement of the joints and usually limitation of movement, especially of extension. The knees, the interphalangeal joints and the shoulders are frequently so affected. Arthritis has occurred as early as 6 years of age (Schiff, 1934; Schwartz and Cooke, 1945), and has been a prominent feature in the older cases. Zeder

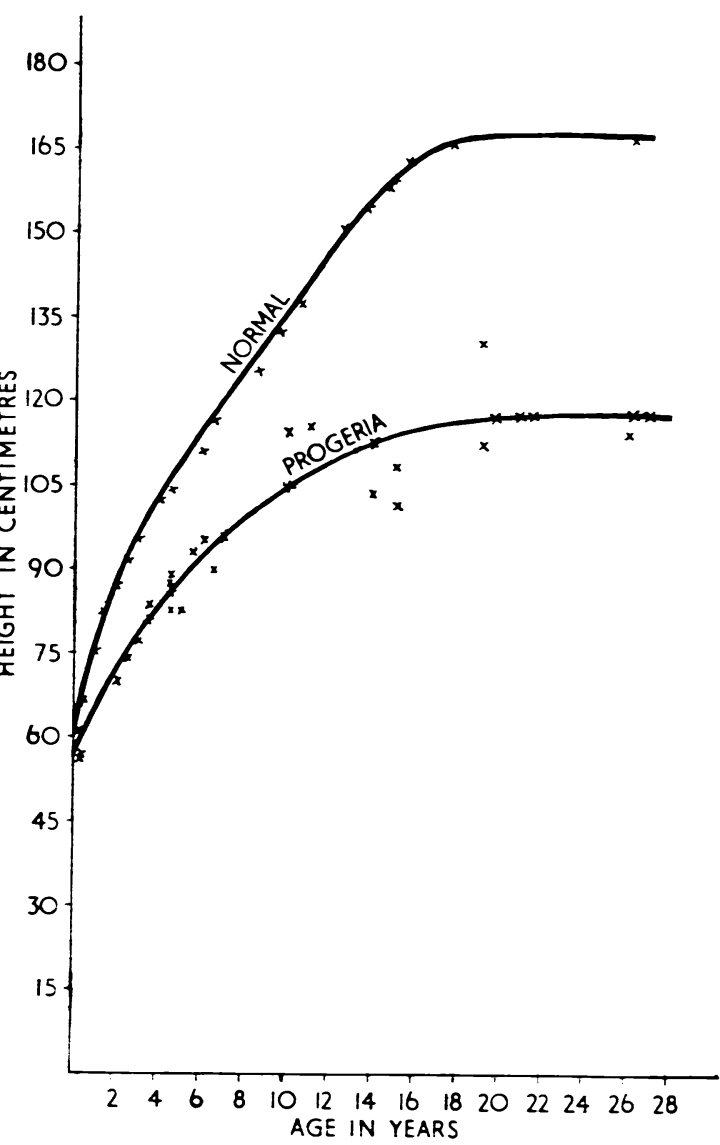

FIG. 13-Growth in height curves in the normal (after Mitchell-Nelson) and in Progeria.

describes the hand as like a 'dead hand' and the posture as ' horse riding.'

The intellect in most cases is normal or above normal. In the earlier years a slightly precocious mentality, as in the case here reported, is characteristic. Later, increasing desire for withdrawal from company, reserve, and attacks of depression tend to occur.

Anginal attacks have occurred as early as the age of 7 years (Talbot et al., 1945) and are reported in most of the older cases. They have usually been of serious significance. Dyspnoea has been marked in some cases but not in others. Hemiplegia at the age of 7 years (Curtin and Kotzen, 1929) and 19 years (Orrico, 1918) has been reported. Where death has occurred preceding clinical evidence of progressive arteriosclerotic and atheromatous changes involving especially the coronary arteries has usually been present, coronary occlusion being the most frequent terminal event. 
Radiologically, thinning and some decalcification of the shafts of the bones, a poorly developed mandible with crowding and abnormal development of the teeth, short clavicles and coxa valga are the most characteristic findings. Enlargement of the sella turcica has been reported previously (Exchaquet, 1935b. Zeder, 1940). The vertebrae tend to retain the ovoid notched infantile shape longer than usual (Brailsford, 1948). Delayed closure of the fontanelle and defective ossification of the bones in the posterior part of the cranium (Thiers and Nahan. 1933; Broc et al., 1935) and arthritic changes in the joints have also been reported. Thiers and Nahan considered their case to have had associated cleidocranial dysostosis. Shortening of the clavicle, however, is a constant feature of all cases of progeria and there is no familial element.

A raised creatine creatinine ratio does not appear to have been recorded previously.

The cytology and chemistry of the blood do not show any characteristic changes. The high serum calcium figures noted by Exchaquet (1935b) and Zeder are unusual. Like the case here reported a raised E.S.R. was noted by Zeder and a raised blood cholesterol level by Exchaquet (1935b). Apart from one case (Orrico, 1918) the Wassermann reaction of the blood has been negative.

Varied electrocardiographic changes have occurred.

Diagnosis. As already stated we reserve the term progeria for cases exhibiting the classical features shown in Hutchinson's and Gilford 's original reports. Such cases are readily recognized after the age of two years. Some of the cases reported as progeria appear to be examples of the Werner syndrome (Thannhauser, 1945), others of ectodermal dysplasia (Harris, 1927). By its absence of hair alopecia totalis in children may present a superficial resemblance to progeria.

Pathology. We are today little nearer an understanding of the pathological processes associated with progeria than Gilford was half a century ago. We can watch the occurrence, over a span of 10 or 15 years, of changes of senility which would normally take five or six times as long to develop. Were we to understand the pathology considerable light might be shed on the processes of ageing. The changes are not, however, merely those of senility. They are those of senility imposed at an infantile stage of development so that infantile characteristics persist side by side with senile ones. This is seen particularly in the bony skeleton, and Keith (1913) has pointed out as infantile characteristics, its small size, the development of the forehead, face, and jaws, the frequent delay in closure of the fontanelle, the thin cranial walls, the persistence of certain cranial sutures, the delay in ossification of certain centres and the shape of some of the bones: and as senile characteristics. the decalcification, the premature fusion of certain sutures, the advanced ossification in certain centres and the arthritic changes. Examples of senile change other than in the skeleton are seen in the presence of atrophic skin and arteriosclerosis.

Few studies of progeria in life have been made. but the metabolic investigations of Talbot et al. on one case are interesting. They concluded (1) that the dietary caloric intake was adequate and that the failure to gain weight was due to an excessive total energy output: (2) that this excessive energy output was not due to hyperthyroidism: (3) that testosterone would increase protein anabolism relative to protein katabolism as shown by an increase in musculature but that this change took place at the expense of other tissues as there was little gain in total weight; (4) that a therapeutic reduction of the total energy output by thiouracil caused a gain in total weight but the possibility that this was due to myxoedema could not be excluded. Other observers have noted a raised basal metabolic rate but the altered skin surface area in progeria may have given false results. The basal metabolic rate has also been reported to be reduced (Popek and Hadlik, 1938).

Raised serum calcium levels were noted by Exchaquet and Zeder and poor calcification of bones is a frequent radiological finding. Both cases showing raised serum calcium were associated with sclerodermia, a condition in which the serum calcium level may be raised (Cornbleet and Struck. 1937).

Post-mortem studies have been reported in four cases (Gilford, 1897; Orrico and Strada, 1927: Manschot, 1940; Talbot et al., 1945). These showed the following constant features: very scant subcutaneous fat although fat was not entirely absent, slender shafts of the long bones with relative width at the epiphyses, marked generalized arteriosclerosis especially in the kidneys and atheroma and calcification of the aorta and coronary arteries with coronary narrowing. In Gilford's case the thymus was enlarged and there was coronary occlusion. The pituitary was not particularly examined. In Orrico's case (Orrico and Strada, 1927) there was well marked hypoplasia and sclerosis of the adrenal cortex. The thyroid was small and only three small parathyroids were found. The testicles were small and there was a complete absence of spermatogenesis. The prostate was small. The pituitary weighed $0.35 \mathrm{~g}$. (normal $0.49 \mathrm{~g}$.) and a large cyst was present in the region of the pars intermedia. The eosinophil cells were normal in 
number but were larger than usual and had finely granular protoplasm. In the case of Talbot et al., the thymus was enlarged, the parathyroids could not be found and the pituitary was asymmetrical and weighed 0.61 g. (normal 0.29 g.). It was not examined microscopically. There was no histological evidence of spermatogenesis. Coronary thrombosis and a myocardial infarction were present. The lateral cranial venous sinuses showed an abnormal course, an interesting finding in view of the cranial bruit present in life. In Manschot's case the heart was enlarged, there was hyaline degeneration and fibrosis of the thyroid, and the parathyroids, three in number, were small and infantile. The pituitary weighed $0.4 \mathrm{~g}$. (normal $0.49 \mathrm{~g}$.), and histologically a deficiency of the eosinophil cells of the anterior lobe was noted. The adrenals were large but the zona granulosa of the adrenal cortex was poorly developed and contained much fat.

The pituitary abnormalities and parathyroid deficiency in the last three cases are interesting, the latter in view of the invariable generalized osteoporosis and occasional high blood calcium level which occur.

The unpublished post-mortem examination by Ebbs (1949) on Parsons' (1949) case showed wasting, premature ageing, coronary occlusion, and coronary artery sclerosis.

Several theories have been advanced to explain the condition. Gilford was impressed by the contrasting features of progeria and acromegaly. His original name for the syndrome he described was in fact micromegaly. In the light of more recent knowledge this contrast between acromegaly and progeria becomes more marked. On the one hand the gigantism, the hirsutism, the thick lips, large tongue, heavy lower jaw, large clavicles, thickened skin, gruff voice and large hands in acromegaly contrast on the other hand with dwarfism, paucity of hair, thin lips. small tongue, underdeveloped lower jaw, short thin clavicles, atrophic skin, piping voice and small hands of progeria. In other words we have in the one case a selective hyperplasia of certain parts and in the other a selective hypoplasia of the same parts. In the late stages of acromegaly when pituitary insufficiency supervenes the skin becomes atrophic and thin, the hair falls out and arteriosclerotic changes may develop. Some contrasting features between cases with tumours of the adrenal cortex and cases of progeria might also be mentioned; the hirsutism, the precocious genital development and the obesity of the former and the absence of hair, the retarded genital development and the thinness of the latter. Variot and Pironneau (1910) considered that the condition was probably of suprarenal origin and Nasso (1925) that it was a polyglandular disturbance with an absolute incapacity of the tissues to develop. Orrico agreed with this view of the polyglandular nature of the condition. Strunz (1929) considered that hypofunction of the anterior lobe of the pituitary was the underlying disturbance and Exchaquet suggested that in his case there might be hypofunction of the acidophil cells of the anterior lobe of the pituitary associated with a basophil adenoma. Zeder considered that the condition was probably a form of pituitary dwarfism and that the parathyroids were particularly influenced by the pituitary dysfunction. He also suggested that the hypothalamus might be involved. Greene and Paterson (1943), in discussing a case of sudden senescence in an adult following a fall, suggested hypothalamic disturbance as the possible cause. Wiedemann (1948) has pointed out the extent to which mesodermal derived tissues are involved in progeria and has elaborated the conception of a constitutional mesenchymal dysplasia.

While the contrast with acromegaly is striking there is some similarity with Simmonds disease. In both there is the appearance of early senility and loss of hair and subcutaneous fat, both may show asthenia and failure of sex function, in both there may be some glandular atrophy especially of the thyroid and adrenals although this latter is not so constant in progeria as it is in Simmonds disease. Nor does progeria show the gross asthenia of Simmonds ${ }^{\circ}$ disease and the myxoedematous changes which may be associated with the latter condition do not occur. Hypoglycaemia and hypoglycaemic attacks are not a feature of progeria nor is hypotension.

We believe from the evidence available that the primary defect in progeria is one of pituitary dysfunction. The marked contrast to acromegaly and points of similarity to Simmonds' disease, both conditions accepted as of pituitary origin, would support this belief. Abnormalities of the sella turcica have been noted radiologically and of the pituitary at post-mortem examination. Radiologically, Exchaquet noted absence of the anterior clinoid processes and deficiency of the posterior clinoids. The fossa was enlarged in Zeder's case and in ours. Keith on the other hand noted that the sella turcica was smaller than normal in the progerian skull he described. Macroscopically the pituitary in Orrico's case showed a cystic abnormality and in the case of Talbot et al., was asymmetrical. Manschot's histological studies showed a deficiency of the eosinophil cells of the anterior lobe, Orrico and Strada's alterations in their size and protoplasm. As hyperfunction of the eosinophil cells of the pituitary may produce the changes of acromegaly it seems logical to deduce that 
hypo-function of these cells at an early age may produce the characteristic changes of progeria.

Treatment. Little can be said about this. No treatment has proved effective. Thyroid, pituitary growth extracts, testosterone, thiouracil, short wave diathermy and ultra violet radiation have been tried without any appreciable benefit. Should the condition prove to be a pituitary hormone deficiency it would seem reasonable to suppose that increased knowledge of the pituitary hormones and the ability to isolate them individually in therapeutically active forms might lead to adequate replacement therapy.

\section{Summary}

A classical case of progeria is described. The world literature relating to this subject is reviewed and it is concluded that this is the nineteenth typical case to be reported. Approximately as many atypical cases have been described and a separate grouping and naming of these is advocated. The clinical features, diagnosis, pathology, and treatment of progeria are discussed. It is suggested that dysfunction of the anterior lobe of the pituitary, possibly of the eosinophil cells, is the underlying lesion.

It is a pleasure to acknowledge our indebtedness to Dr. J. H. Prain who has carried out the biochemical estimations, to Drs. G. M. Grant, T. Sprunt and W. C. Swanson for the radiological examinations, and to Drs. M. G. Green, D. Grewar and Mr. Allan for the photographs. Figs. 1 and 2 are reproduced by kind permission of the Editors of the Proceedings of the Royal Society of Medicine. The British Council has given valuable help in obtaining some of the rarer references.

\section{REFERENCES}

Apert, E., (1933). 'Infantilism,' p. 70. Trans. by Ellis, R. W. B., London.

Apert, E., and Robin P. (1927). Pr. méd., 28, 433.

Atkinson, F. R. B. (1937). Med. Pr., 194, 34.

Barraud, G. (1934). Gaz. méd. France, 41, 983.

Bolhuis, J. H. van (1948). Ned. Tijdschr. Geneesk., 92, 1667.

Brailsford, J. F. (1948). 'The Radiology of Bones and Joints,' 4th ed., p. 43. London.

Broc, R., Nicolle, M., and de Beaujeau, A. V. (1935). Pr. méd., 43, 786.

Cornbleet, T., and Struck, H. C. (1937). Arch. Derm. Syph., Chicago, 35, 188.

Crooke, A. C. (1948). In 'The Practice of Endocrinology.' Ed. Greene, R., London.

Curtin, V. T., and Kotzen, H. F. (1929). Amer. J. Dis. Child., 38, 993.

Ebbs, J. H. (1949). Personal Communication.

Exchaquet, L. (1935a). Rev. méd. Suisse rom., 55, 248.

- (1935b). Rev. franc. Pédiat., 11, 467.

Farran-Ridge, C. (1921). J. Neurol. Psychopath., 2, 254.
Gilford, H. (1897). Med. chir. Trans., 80, 17.

(1902). Brit. med. J., $2,1408$.

(1904a). Practitioner, 73, 188.

(1904b). Brit. med. J., $2,914$.

(1911a). 'Disorders of post-natal growth and development.' London.

(1911b). Brit. J. Child. Dis., 8, 292.

(1913). Lancet, 1, 412.

Gorter, E. (1942). Maandschr. Kindergeneesk., 12, 53.

Gottron, H. (1940). Arch. Derm. Syph., Wien., 181, 571.

Greene, R., and Paterson, A. S. (1943). Lancet, 2, 158. (1948). 'The Practice of Endocrinology.' London.

Halle, J., and Odinet, J. (1932). Bull. Soc. Pédiat., Paris, $30,326$.

Hamburger, L. P. (1931). Amer. J. med. Sci., 181, 756. Harris, C. F. (1927-28). Proc. R. Soc. Med., 21, 227.

Heuyer, G., Denoyelle, L., and Bernard, A. (1936). Bull. Soc. Pédiat., Paris, 34, 159.

Hutchinson, J. (1886). Med. chir. Trans., 69, 473.

Keith, A. (1913). Lancet, 1, 305.

Korsgaard, R. (1940). Ugeskr. Laeg., 102, 309.

Lereboullet, P. (1917). Paris méd., 19, 118.

Louw, A. (1946). Nord Med., 31, 2067.

Manschot, W. A. (1940). Ned. Tijdschr. Geneesk., 84, 3774.

Martinez, C. H. (1935). Crón. méd., Lima, 52, 372.

Mitchell, E. C., and Goltman, D. W. (1940). Amer. J. Dis. Child., 59, 379.

Mitchell-Nelson (1945). In 'Text-Book of Pediatrics.' Edited by Nelson, W. E. 4th ed. Philadelphia.

Moehlig, R. C. (1946). J. Amer. med. Ass., 132, 640.

Müller-Hess, B. (1940). J. Kinderheilk., 62, 96.

Nasso, I. (1925). Pediatria, 33, 1213.

Nery, O. (1944). Cultura méd., Rio de J., 6, 186.

Orrico, J. (1918). Prensa méd. argent., 5, 133.

-, and Strada, F. (1927). Arch. méd. Enf., 30, 385.

Parsons, L. G. (1949). Personal Communication.

Paterson, D. (1922-23). Proc. R. Soc. Med., 16, Sec. Dis. Child., 42.

Popek, K., and Hadlik, J. (1938). Čas. Lék. čes., 77, $11,58,81$.

Pouzin-Malègue, Y. (1932). Bull. Soc. Pédiat., Paris, 30, 685 .

Rand, C. W. (1914). Boston med. surg. J., 171, 107.

Schachter-Nancy, M. (1938). Bull. méd., Paris, 52, 244.

Schiff, E. (1934). Schweiz. med. Wschr., 64, 213.

Schippers, J. C. (1916). Ned. Tijdschr. Geneesk., 2, 2274.

Schondel, A. (1943). Acta paediatr., Stockh., 30, 286.

Schwartz, A. S., and Cooke, J. V. (1945). Biol. Symp., 11, 96.

Stern, A., and Lieberman, D. P. (1937). Arch. Pediat., $54,169$.

Stoia, I., and Andreoiu, C. (1928). Spitalul, 48, 349.

Strunz, F. (1929). Z. Kinderheilk., 47, 401.

Sundblad, R. (1938). Arch. argent. Pediat., 9, 624.

Talbot, F. (1923). Mschr. Kinderheilk., 25, 643.

Talbot, N. B., Butler, A. M., Pratt, E. L., MacLachlan, E. A., and Tannheimer, J. (1945). Amer. J. Dis. Child., 69, 267.

Thannhauser, S. J. (1945). Ann. intern. Med., 23, 559.

Thiers, J., and Nahan (1933). J. Radiol. Électrol., 17, 675.

Variot and Pironneau (1910). Bull. Soc. Pédiat., 12, 431.

Waldorp, C. P., and del Castillo, E. B. (1928). Pr. méd., 36, 1221 .

Wiedemann, H. R. (1948). Z. Kinderheilk., 65, 670. (1948). Arch. Kinderheilk., 135, 169.

Zeder, E. (1940). Mschr. Kinderheilk., 81, 167. 